\title{
E-Learning during the Covid-19 Pandemic in Spain: A Case Study with High School Mathematics Students
}

\section{Lidon Moliner ${ }^{1}$ \\ Gil Lorenzo-Valentin ${ }^{2}$ Francisco Alegre ${ }^{3 \rtimes}$}

${ }^{2,3}$ Universitat Jaume I of Castellon, Spain.

Email:mmoliner@ujies Tel:+0034964729806

'Email:valentin@uji.es Tel: +0034964729794

'Email:falegre@uji.es Tel: +o034964729806

Abstract

The covid-19 pandemic has significantly altered the organization and scheduling of high schools in Spain. Due to pandemic restrictions, most students from grades 9 to 11 come to class only on alternate days. In this situation, e-learning and distance learning have gained prominence as necessary methods of instruction. In this study 68 students from grades 9 and 10, attending on alternate days, participated in an online teaching experience for the first time in their lives. This took place during the first trimester of the 2020-2021 academic school year. On days when they did not attend class in person, students were expected to watch the mathematics classes which were broadcasted live via YouTube. Students could either watch the classes live and ask the teacher questions via an online chat, or alternatively, they could watch the pre-recorded classes at a later time. The two options were analyzed using quantitative and qualitative methods. Results showed a continuous decrease in the number of students who preferred the first option, switching progressively from online live classes to pre-recorded classes as the weeks passed. The qualitative results explained this progressive decrease as students preferred to watch the teacher's explanations several times. Although e-learning is absolutely necessary in the 21 st century, and especially during the current pandemic, controlling students' level of application to distance work and online learning is still a challenge.

Keywords: Online learning, Mathematics, Covid-19, High school, Spain, YouTube.

Citation | Lidon Moliner; Gil Lorenzo-Valentin; Francisco Alegre (2021). E-Learning during the Covid-19 Pandemic in Spain: A Case Study with High School Mathematics Students. Journal of Education and e-Learning Research, 8(2): 179-184.

History:

Received: 4 February 2021

Revised: 8 March 2021

Accepted: 6 April 2021

Published: 27 April 2021

Licensed: This work is licensed under a Creative Commons

Attribution 3.0 License $(\mathrm{cc})$ E

Publisher: Asian Online Journal Publishing Group
Acknowledgement: All authors contributed to the conception and design of the study.

Funding: This study received no specific financial support.

Competing Interests: The authors declare that they have no conflicts of interest.

Transparency: The authors confirm that the manuscript is an honest, accurate, and transparent account of the study was reported; that no vital features of the study have been omitted; and that any discrepancies from the study as planned have been explained.

Ethical: This study follows all ethical practices during writing.

\section{Contents}

1. Introduction .......................... 180

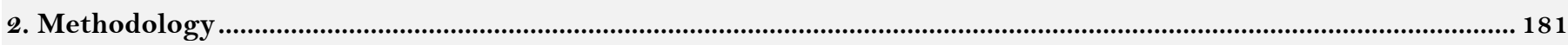

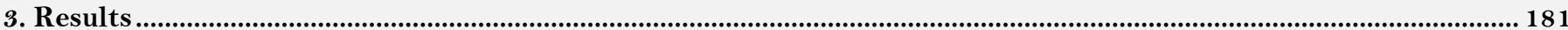

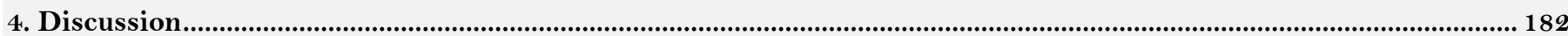

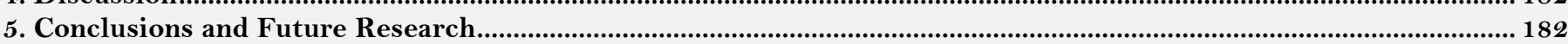

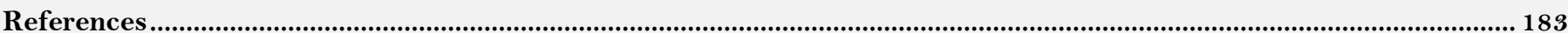




\section{Contribution of this paper to the literature}

This study aims to contribute to the existing research literature on e-learning and covid-19. Before the covid-19 pandemic almost $100 \%$ of the high schools in Spain had in-person classes and the use of elearning in secondary education was very marginal. To achieve social distancing, most high school students attend class on alternate days. In this situation, e-learning is arguably the only possible solution for students and teachers to keep learning in a way and at a rate that is similar to attending class every day. The novelty of the study resides in the fact that this is the first time that students have enrolled in an e-learning experience over a prolonged period of time. The way students adapt to this sudden new way of learning is analyzed. Moreover, the students' learning preferences when given the option to watch live classes vs pre-recorded classes are also investigated. Students' personal responsibility in e-learning is discussed and possibilities for further research are indicated.

\section{Introduction}

\subsection{Covid-19 and E-Learning.}

The covid-19 pandemic has brought about significant changes to the teaching and learning methods of schools, high schools and universities world-wide (Dong, Cao, \& Li, 2020; Huang et al., 2020). Only those universities which already embraced distance or online learning were not forced to significantly alter their instruction methods (George, 2020). In fact, this type of institution has not derived any major impact from the covid-19 pandemic (Adnan \& Anwar, 2020; Dhawan, 2020; Rapanta, Botturi, Goodyear, Guàrdia, \& Koole, 2020). For other institutions, teaching and learning during this pandemic presents an ongoing challenge. Even though institutions worldwide have carried out various organizational efforts and teachers have done their best to adapt to this unexpected situation, resources and economical investments have proved to be limited (Demuyakor, 2020; Gardner, 2020). The case for elementary, middle- and high school institutions is even worse in this sense, as the impact of the covid-19 pandemic on the educational learning processes has been even greater (Aliyyah et al., 2020; Fauzi \& Khusuma, 2020; Korkmaz \& Toraman, 2020). Although even students' parents have done their best to help their children (Garbe, Ogurlu, Logan, \& Cook, 2020; Novianti \& Garzia, 2020) the obstacles and barriers for both teachers and students have been significant. Moreover, several authors have highlighted and drawn attention to the importance of digital competence for learning during the pandemic. Just because their children are familiar with digital devices, many parents expect their children to be proficient enough to enroll in online or electronic learning, which often proves not to be the case (Akçayır, Dündar, \& Akçayır, 2016; Kirschner \& De Bruyckere, 2017; Nowak, 2019; Yong, Gates, \& Harrison, 2016). In this sense, the situation brought about by the covid-19 pandemic has shown more clearly than ever students' lack of digital competence (Iivari, Sharma, \& Ventä-Olkkonen, 2020; Tejedor, Cervi, Pérez-Escoda, \& Jumbo, 2020).

\subsection{Research Gap}

The covid-19 pandemic has significantly altered the way in which most educational centers worldwide organize their learning process. The practice of students attending on alternate days or weeks to slow the spread of the virus has given rise to the implementation of more e-learning and distance learning experiences. In an unexpected situation, teachers, students and students' families have had to cope with this new way of learning. The communication between teachers and students has been altered and interactions among students have been modified. Suddenly, everybody has had to learn to cope with a situation in which many of the implicated agents do not have the required digital competences. The process of adapting to this new learning environment is an issue that has yet to be studied thoroughly, and offers, therefore, an important research gap. In this study we examine how high school students have embraced e-learning during the covid-19 pandemic in Spain while attending school in person on alternate days.

\subsection{The Educational Organization Due to Covid-19 in Spain}

Some weeks after the 2019-2020 school year ended, the national and regional governors concluded that the best proposal for students in grades 8 to 11 during the 2020-2021 school year was to attend on alternate days if high schools could not meet the social distancing measures required by the national government. Given the fact that in Spain classrooms are usually relatively small, with a low surface per student ratio, it was evident that most of the students in these grades would have to attend on alternate days. Teachers were given one to two months to prepare for this scenario. In Spain, during the last trimester of the 2019-2020 school year (March to June) students had remained at home due to a nationwide covid-19 lockdown. Hence, distance learning was the only option. Only those students who had to take their university access exams attended some classes in person or took exams in person. The other students, at all educational levels, were mostly assigned tasks to complete at home, and no inperson exams were allowed, due to the above-mentioned lockdown (Area-Moreira, Bethencourt-Aguilar, MartínGómez, \& San Nicolás-Santos, 2020). Although this situation fostered students' autonomous learning and their digital competences increased (Gonzalez et al., 2020) it was evident that students and teachers were not provided with the necessary electronic resources and online tools due to the fast improvisation made necessary by the sudden lockdown (Ramos-Morcillo, Leal-Costa, Moral-García, \& Ruzafa-Martínez, 2020; Tejedor et al., 2020).

\subsection{Looking for the Best Online Teaching Platform}

The experience reported in this manuscript took place in the Valencian Community (Spain). The regional government provided teachers and students with two main electronic teaching platforms. The first, called "Aules", was a typical virtual classroom in which the teacher could assign tasks, report qualifications and send messages very similar to Google Classroom (Al-Maroof \& Al-Emran, 2018; Heggart \& Yoo, 2018; Iftakhar, 2016). The second was Webex (Marinescu, 2017; Nicklen, Keating, Paynter, Storr, \& Maloney, 2016). Over the last few years, Webex has been widely used in learning and teaching worldwide and its usage has increased during the pandemic (Azlan et al., 2020; Dinata, Sakman, \& Syarpin, 2020). This was the platform most used to arrange online meetings among teachers. It was regarded as a safe platform and its reliability was consistent (Nogales-Delgado, Suero, \& Martin, 2020). Nevertheless, it was not seen as an intuitive platform by students and certain limitations became 
apparent that concerned the researchers of this study, such as low image and sound quality and the fact that it had been conceived as an e-meeting software tool (Eustace, Henri, Jahn, Piesche, \& Jablonski, 2012; Garcia, Uria, Granda, Suarez, \& Gonzalez, 2007). Hence, the search for the best online teaching platform was based on four main criteria: free-of-charge, intuitive for students, reliable and high image and sound quality. Although students were very enthusiastic about some recent platforms, such as Twitch (Johnson \& Woodcock, 2019; Payne, Keith, Schuetzler, \& Giboney, 2017) in the end YouTube Studio was selected.

\subsection{Why YouTube Studio?}

YouTube Studio offered various features that were ideal for the teaching of mathematics in high school. The fact that it offered both a live broadcast and a recorded video that could be accessed at any time was highly valued by the researchers. Moreover, the link to the video could be "hidden", that is, only made available to the person who received the link. In this way, the explanations, questions and comments could be restricted to the students in each class or grade and were not publicly available. The comments section and the available online chat were also regarded as valuable by the researchers from a learning perspective, as students could post their questions at any time. Finally, the reliability and quality of image and sound were also taken into account.

\section{Methodology}

\subsection{Participants}

68 students from grades 9 and 10, attending on alternate days, participated in an online teaching experience for the first time in their lives. Of these, 49 were $9^{\text {th }}$ grade students and the other 19 were $10^{\text {th }}$ grade students. The experience took place at a public high school in the province of Castellon in the Valencian Region (Spain).

\subsection{Implementation}

During the first trimester of the 2020-2021 school year, participants in this study were sent a link for each online class. Every session half of them were in class and the other half were at home. Each student was sent the link for each session. The link was sent by email to all students so that those who were in the classroom could also watch the explanations back at any time. The link was "hidden", that is, only the students in the session could access that YouTube live broadcast or video. Students not attending in-person were given two options. The first option was to watch the classes live and ask the teacher questions via the YouTube online chat and comments section. The second option was to watch the YouTube video that was generated after the YouTube live broadcast and that remained permanently available to them. The sessions were recorded in hd 1080 using a Logitech Webcam C922 Pro Stream and an AverMedia AM310 Microphone. The camera was focused on the blackboard, so students could follow the explanations provided by the teacher while he was writing on the board.

\subsection{Quantitative and Qualitative Information from the Study \\ 2.3.1. Quantitative Data}

The daily average views per video and the average hours of time watching each video were monitored using the analytics provided by YouTube Studio. The teacher took note of the number of people that were watching each live session and verified it through the information that appeared on the YouTube screen during each broadcast.

\subsubsection{Qualitative Data}

Discussion groups (O’Connor, Meredith, McNamara, O’Hora, \& Kinsella, 2020; Riyahi \& Sohrabi, 2020) and semi-structured interviews (Brown \& Danaher, 2019) were held with the students. A total of four discussion groups with three students in each were carried out.

\section{Results}

The results are reported in two subsections below. First, the quantitative results are shown. Secondly, the qualitative results are reported.

\subsection{Quantitative Results}

The quantitative results of the study showed a progressive decrease in the number of live visualizations per day, which meant most of the students switched to watching the pre-recorded classes. The initial enthusiasm and commitment by the students led to an average 8.11 hours of watch time, which implied that almost $100 \%$ of the students were watching the online classes. By the end of the trimester, this had fallen to a reduced 3.16 hours, which meant most of the students were not watching the videos, either live or pre-recorded (see Figure 1). The total average of visualizations per week also experienced a progressive decrease, dropping from 69 to 13 views, see Figure 2.

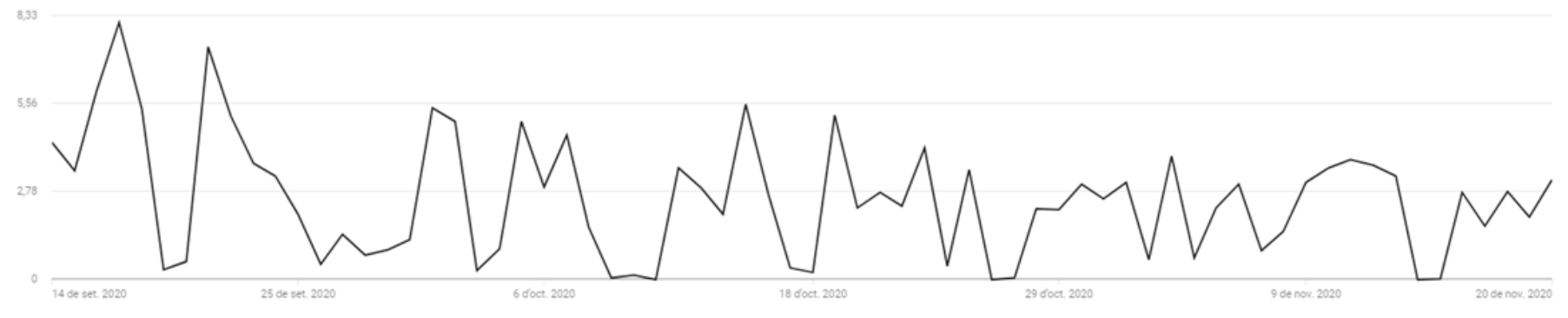

Figure-1. Daily average viewing time in hours. 


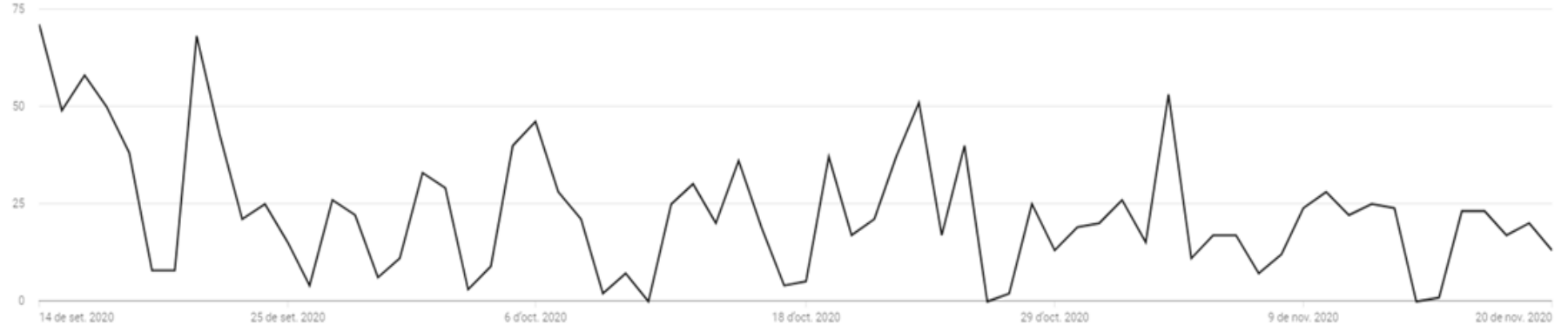

Figure-2. Total average visualizations per week.

\subsection{Qualitative Results}

In line with the quantitative results, the qualitative results also reported that students preferred watching the pre-recorded classes to attending the live lessons. The main reason given was that the teacher's explanations were repeated several times, so students felt that with this option they could save time and better organize their daily workload. "When you are watching the class live, time never passes. It's eternal! It's way different than being in class," said Timmy (names have been changed for anonymity purposes). "I prefer to watch it pre-recorded, as I can watch an explanation over and over again. Yes, you can ask the teacher, but I prefer to watch it calmly as many times as I want. It's less stressful," said Johanne. "I started watching the classes live like everybody else, but after a few weeks, I realized I could save time by watching them pre-recorded. I could skip all the parts that were not so important to me and go straight to the teacher's explanations or skip forward in the video to the point where the exercises and problems were completely solved," said Martin. Many interviewed students also indicated that the pre-recorded option was more convenient as the exam weeks drew closer. "No disrespect, but I'm not going to watch the class live on Thursday when I have two exams on Friday. I will watch it on the weekend when I have plenty of time," said Ivette. Some students also indicated that they did not watch the classes live because it was too early in the morning or almost time for lunch. "You know, to watch it live on Tuesday I have to wake up early. If I can sleep for two more hours, I prefer to watch it later," said Austin. Many students recognized that eventually, as the weeks passed, they were less responsible and did not watch many of the sessions. "I felt bad because I knew I had to watch it at some point. I was like I will watch it later. Then I thought about watching it on the weekend. I didn't. Then I want to class, and I didn't understand anything because I had skipped two sessions and so on, until it was too much and I thought to ask a friend who could explain it to me," said Stephen.

\section{Discussion}

The progressive downfall reported in this study is consistent with previous analogous studies in the field (Al Sabah, 2020; Arrosagaray, González-Peiteado, Pino-Juste, \& Rodríguez-López, 2019; Gudmundsdottir, Gassó, Rubio, \& Hatlevik, 2020). Authors such as Firat (2016); Lorenzo and Lorenzo (2019); Sugawara, Okuhara, and Sato (2020); Yaniawati, Kariadinata, Sari, Pramiarsih, and Mariani (2020) have described a similar effect in their elearning experiences. In the beginning, during the first e-learning sessions, students usually show high levels of enthusiasm and commitment (Alhabeeb \& Rowley, 2018; Lee, Song, \& Hong, 2019; So, Chen, \& Wan, 2019) and even more so if this is the first time that they have ever taken classes this way (Karim, Shahed, Rahman, \& Mohamed, 2019; Suryaman et al., 2020). As indicated by several authors, individual responsibility is a must when participating in this type of learning experience (Houlden \& Veletsianos, 2019; Ozhan \& Kocadere, 2020; Wong et al., 2019). Taking into account that many high school students are not yet mentally mature enough to take ownership of their own learning responsibility, it was predictable that many of the students would not watch the classes live, or simply not watch them at all (Peterka-Benton \& Benton, 2019; Siqin \& Chu, 2019). Important differences may be found in the literature regarding university students' responsibility compared to high school students (Harlow \& Bowman, 2016; Rai \& Khanal, 2017). Hence, although e-learning has been firmly established in universities worldwide for over a decade, that is still not the case in high school education (Ebner et al., 2020; Sharma, Palvia, \& Kumar, 2017) and one of the main reasons is the underdeveloped level of high school students' responsibility (Tshewang, Chandra, \& Yeh, 2017). In online learning environments, the teacher is, as always, responsible for the students' learning, but it's also the students' responsibility to make the appropriate effort to learn (Borup \& Stimson, 2019; Wu, 2018). A student can click on the link provided and be watching the live class, but still not complete any tasks at all. In this sense, monitoring and controlling students' attendance and work during online classes is still a significant challenge in the 21st century (Park \& Yun, 2018; Shu \& Gu, 2018).

\section{Conclusions and Future Research}

It can be concluded that most high school students may not yet be responsible enough to partake in this type of e-learning on alternate days. Although e-learning is absolutely necessary in the $21^{\text {st }}$ century, and even more so during the current pandemic, controlling students' level of application during distance work and online learning is still a challenge (Nortvig, Petersen, \& Balle, 2018; Sulistyaningsih \& Aziz, 2018). In any kind of learning environment, it is necessary for students to take personal responsibility, but this can be considered crucial in online and electronic learning contexts (Bulić \& Kostović Vranješ, 2019). Readers must bear in mind that this experience was carried out with $9^{\text {th }}$ and $10^{\text {th }}$ grade students, which are the final years of compulsory secondary education in Spain. Outcomes may have been different if the study had concerned grade 11 and 12 (non-compulsory education), taking into account that there is a ferocious academic competition in those years to secure places in university. Future studies may shed more light upon this issue. Moreover, it is also unclear what may have happened if the students had only been given the option to watch the classes live. Further research is needed to examine the effects of the use of monitoring and controlling tools on high school students' online attendance to mathematics classes (Titarenko \& Little, 2017). Finally, the relationships between this type of learning and variables such as academic achievement (Lo \& Hew, 2020) mathematics self-concept (Lidon Moliner \& Francisco Alegre, 2020) or mathematics anxiety (Lidón Moliner \& Francisco Alegre, 2020) also emerge as interesting avenues of research. 


\section{References}

Adnan, M., \& Anwar, K. (2020). Online learning amid the COVID-19 Pandemic: Students' Perspectives. Online Submission, 2(1), 45-51. Available at: https://doi.org/10.33902/jpsp.2020261309.

Akçayır, M., Dündar, H., \& Akçayır, G. (2016). What makes you a digital native? Is it enough to be born after 1980? Computers in Human Behavior, 60, 435-440. Available at: https://doi.org/10.1016/j.chb.2016.02.089.

Al-Maroof, R. A. S., \& Al-Emran, M. (2018). Students acceptance of google classroom: An exploratory study using PLS-SEM approach. International Journal of Emerging Technologies in Learning, 13(6), 112-123. Available at: https://doi.org/10.3991/ijet.v 13io6.8275.

Al Sabah, Y. (2020). E-learning and ICT in education at Palestinian Schools: Towards 21 st century skills. Palestinian Journal for Open Learning $\mathcal{E}^{2}$ e-Learning, 8(14), 1-14.

Alhabeeb, A., \& Rowley, J. (2018). E-learning critical success factors: Comparing perspectives from academic staff and students. Computers $\bigotimes^{\circ}$ Education, 127, 1-12. Available at: https://doi.org/10.1016/j.compedu.2018.08.007.

Aliyyah, R. R., Rachmadtullah, R., Samsudin, A., Syaodih, E., Nurtanto, M., \& Tambunan, A. R. S. (2020). The perceptions of primary school teachers of online learning during the COVID-19 pandemic period: A case study in Indonesia. Journal of Ethnic and Cultural Studies, 7(2), 90-109. Available at: https://doi.org/10.29333/ejecs/388.

Area-Moreira, M., Bethencourt-Aguilar, A., Martín-Gómez, S., \& San Nicolás-Santos, M. B. (2020). Analysis of university teaching policies in Spain in times of Covid-19. The adapted presence. Journal of Distance Education (RED), 21(65), 1-19. Available at: https://doi.org/10.6018/red.450461.

Arrosagaray, M., González-Peiteado, M., Pino-Juste, M., \& Rodríguez-López, B. (2019). A comparative study of Spanish adult students' attitudes to ICT in classroom, blended and distance language learning modes. Computers $\&^{2}$ Education, 134, 31-40. Available at: https://doi.org/10.1016/j.compedu.2019.01.016.

Azlan, C. A., Wong, J. H. D., Tan, L. K., Huri, M. S. N. A., Ung, N. M., Pallath, V., . . Ng, K. H. (2020). Teaching and learning of postgraduate medical physics using Internet-based e-learning during the COVID-19 pandemic-A case study from Malaysia. Physica Medica, 80, 10-16. Available at: https://doi.org/10.1016/j.ejmp.2020.10.002.

Borup, J., \& Stimson, R. J. (2019). Responsibilities of online teachers and on-site facilitators in online high school courses. American Journal of Distance Education, 33(1), 29-45. Available at: https://doi.org/10.1080/08923647.2019.1554984.

Brown, A., \& Danaher, P. A. (2019). CHE principles: Facilitating authentic and dialogical semi-structured interviews in educational research. International Journal of Research $\oint^{\circ}$ Method in Education, 42(1), 76-90. Available at: https://doi.org/10.1080/1743727x.2017.1379987.

Bulić, M., \& Kostović Vranješ, V. (2019). The impact of e-learning on student selfresponsibility in doing their homework. Školski Vjesnik: Journal for Pedagogical Theory and Practice, 68(1), 127-140.

Demuyakor, J. (2020). Coronavirus (COVID-19) and online learning in higher institutions of education: A survey of the perceptions of Ghanaian international students in China. Online Journal of Communication and Media Technologies, 10(3), e202018. Available at: https://doi.org/10.29333/ojcmt/8286.

Dhawan, S. (2020). Online learning: A panacea in the time of COVID-19 crisis. Journal of Educational Technology Systems, 49(1), 5-22. Available at: https://doi.org/10.1177/0047239520934018.

Dinata, P. A. C., Sakman, S., \& Syarpin, S. (2020). Blended learning training assisted by webex meeting and mentimeter to streamline teaching and learning activities. Bubungan Tinggi: Journal of Community Service, 2(2), 64-72.

Dong, C., Cao, S., \& Li, H. (2020). Young children's online learning during COVID-19 pandemic: Chinese parents' beliefs and attitudes. Children and Touth Services Review, $118(1)$, 105440. Available at: https://doi.org/10.1016/j.childyouth.2020.105440.

Ebner, M., Schön, S., Braun, C., Ebner, M., Grigoriadis, Y., Haas, M., . . . Taraghi, B. (2020). COVID-19 epidemic as E-learning boost? Chronological development and effects at an Austrian university against the background of the concept of "E-Learning Readiness". Future Internet, $12(6)$, 1-20. Available at: https://doi.org/10.3390/fi12060094.

Eustace, K., Henri, J., Jahn, M., Piesche, C., \& Jablonski, S. (2012). Flexibility requirements concerning the design of synchronous e-learning systems. Interactive Technology and Smart Education.

Fauzi, I., \& Khusuma, I. H. S. (2020). Teachers' elementary school in online learning of COVID-19 pandemic conditions. Jurnal Iqra': Kajian Ilmu Pendidikan, 5(1), 58-70. Available at: https://doi.org/10.25217/ji.v5i1.914.

Firat, M. (2016). Measuring the e-learning autonomy of distance education students. Open Praxis, 8(3), 191-201. Available at: https://doi.org/10.5944/openpraxis.8.3.310.

Garbe, A., Ogurlu, U., Logan, N., \& Cook, P. (2020). Parents' experiences with remote education during COVID-19 school closures. American Journal of Qualitative Research, 4(3), 45-65. Available at: https://doi.org/10.29333/ajqr/8471.

Garcia, D. F., Uria, C., Granda, J. C., Suarez, F. J., \& Gonzalez, F. (2007). A functional evaluation of the commercial platforms and tools for synchronous distance e-learning. International Journal of Education and Information Technologies, 1(2), 95-104.

Gardner, L. (2020). Covid-19 has forced higher ed to pivot to online learning. Here are 7 takeaways so far. The Chronicle of Higher Education, 20 .

George, M. L. (2020). Effective teaching and examination strategies for undergraduate learning during COVID-19 school restrictions. Journal of Educational Technology Systems, 49(1), 23-48. Available at: https://doi.org/10.1177/0047239520934017.

Gonzalez, T., De La Rubia, M., Hincz, K. P., Comas-Lopez, M., Subirats, L., Fort, S., \& Sacha, G. (2020). Influence of COVID-19 confinement on students' performance in higher education. PloS One, 15(10), e0239490. Available at: https://doi.org/10.35542/osf.io/9zuac.

Gudmundsdottir, G. B., Gassó, H. H., Rubio, J. C. C., \& Hatlevik, O. E. (2020). Student teachers' responsible use of ICT: Examining two samples in Spain and Norway. Computers $\mathcal{E}^{\circ}$ Education, 152(1), 103877. Available at: https://doi.org/10.1016/j.compedu.2020.103877.

Harlow, A. J., \& Bowman, S. L. (2016). Examining the career decision self-efficacy and career maturity of community college and firstgeneration students. Journal of Career Development, 43(6), 512-525. Available at: https://doi.org/10.1177/0894845316633780.

Heggart, K. R., \& Yoo, J. (2018). Getting the most from google classroom: A pedagogical framework for tertiary educators. Australian Journal of Teacher Education, 43(3), 140-153. Available at: https://doi.org/10.14221/ajte.2018v43n3.9.

Houlden, S., \& Veletsianos, G. (2019). A posthumanist critique of flexible online learning and its "anytime anyplace" claims. British Journal of Educational Technology, 50(3), 1005-1018. Available at: https://doi.org/10.1111/bjet.12779.

Huang, R., Tlili, A., Chang, T.-W., Zhang, X., Nascimbeni, F., \& Burgos, D. (2020). Disrupted classes, undisrupted learning during COVID19 outbreak in China: Application of open educational practices and resources. Smart Learning Environments, 7(1), 1-15.

Iftakhar, S. (2016). Google classroom: what works and how. Journal of Education and Social Sciences, 3(1), 12-18.

Iivari, N., Sharma, S., \& Ventä-Olkkonen, L. (2020). Digital transformation of everyday life-How COVID-19 pandemic transformed the basic education of the young generation and why information management research should care? International Journal of Information Management, 55(1), 102183. Available at: https://doi.org/10.1016/j.ijinfomgt.2020.102183.

Johnson, M. R., \& Woodcock, J. (2019). 'It's like the gold rush': The lives and careers of professional video game streamers on Twitch. tv. Information, Communication E' Society, 22(3), 336-351. Available at: https://doi.org/10.1080/1369118x.2017.1386229.

Karim, A., Shahed, F. H., Rahman, M. M., \& Mohamed, A. R. (2019). Revisiting innovations in ELT through online classes: An evaluation of the approaches of 10 minute school. Turkish Online Journal of Distance Education, 20(1), 248-266.

Kirschner, P. A., \& De Bruyckere, P. (2017). The myths of the digital native and the multitasker. Teaching and Teacher Education, 67, 135-142. Available at: https://doi.org/10.1016/j.tate.2017.06.001.

Korkmaz, G., \& Toraman, Ç. (2020). Are we ready for the post-COVID-19 educational practice? An investigation into what educators think as to online learning. International Journal of Technology in Education and Science, 4(4), 293-309. Available at: https://doi.org/10.46328/ijtes.v4i4.110.

Lee, J., Song, H.-D., \& Hong, A. J. (2019). Exploring factors, and indicators for measuring students' sustainable engagement in e-learning. Sustainability, $11(4)$, 985. Available at: https://doi.org/10.3390/su1 1040985. 
Lo, C. K., \& Hew, K. F. (2020). A comparison of flipped learning with gamification, traditional learning, and online independent study: The effects on students' mathematics achievement and cognitive engagement. Interactive Learning Environments, $28(4), 464-481$. Available at: https://doi.org/10.1080/10494820.2018.1541910.

Lorenzo, C., \& Lorenzo, E. (2019). Opening up higher education: An e-learning program on service-learning for university students. Paper presented at the International Conference on Applied Human Factors and Ergonomics (pp. 27-38). Springer, Cham.ç.

Marinescu, V. (2017). Teaching area studies through two different on-line platforms. Brain. Broad Research in Artificial Intelligence and Neuroscience, 8(3), 38-46.

Moliner, L., \& Alegre, F. (2020). Effects of peer tutoring on middle school students' mathematics self-concepts. PloS one, 15(4), e0231410. Available at: https://doi.org/10.1371/journal.pone.0231410.

Moliner, L., \& Alegre, F. (2020). Peer tutoring effects on students' mathematics anxiety: A middle school experience. Frontiers in Psychology, 1 1(1610), 1-12. Available at: https://doi.org/10.3389/fpsyg.2020.01610.

Nicklen, P., Keating, J., Paynter, S., Storr, M., \& Maloney, S. (2016). Remote-online case-based learning: A comparison of remote-online and face-to-face, case-based learning-a randomized controlled trial. Education for Health (Abingdon, England), 29(3), 195-202.

Nogales-Delgado, S., Suero, S. R., \& Martin, J. M. E. (2020). COVID-19 outbreak: Insights about teaching tasks in a chemical engineering laboratory. Education Sciences, 1O(9), 1-13. Available at: https://doi.org/10.3390/educsci10090226.

Nortvig, A.-M., Petersen, A. K., \& Balle, S. H. (2018). A literature review of the factors influencing E-learning and blended learning in relation to learning outcome, student satisfaction and engagement. Electronic Journal of E-learning, 16(1), 46-55.

Novianti, R., \& Garzia, M. (2020). Parental engagement in children's online learning during COVID-19 pandemic. Journal of Teaching and Learning in Elementary Education, 3(2), 1 17-131. Available at: https://doi.org/10.33578/jtlee.v3i2.7845.

Nowak, B. M. (2019). The development of digital competence of students of teacher training studies--polish cases. International Journal of Higher Education, 8(6), 262-266. Available at: https://doi.org/10.5430/ijhe.v8n6p262.

O'Connor, T., Meredith, D., McNamara, J., O'Hora, D., \& Kinsella, J. (2020). Farmer discussion groups create space for peer learning about safety and health. Journal of Agromedicine, 1-12. Available at: https://doi.org/10.1080/1059924x.2020.1720882.

Ozhan, Ş. Ç., \& Kocadere, S. A. (2020). The effects of flow, emotional engagement, and motivation on success in a gamified online learning environment. Journal of Educational Computing Research, 57(8), 2006-2031. Available at: https://doi.org/10.1177/0735633118823159.

Park, S., \& Yun, H. (2018). The influence of motivational regulation strategies on online students' behavioral, emotional, and cognitive engagement. American Journal of Distance Education, 32(1), 43-56. Available at: https://doi.org/10.1080/08923647.2018.1412738.

Payne, K., Keith, M. J., Schuetzler, R. M., \& Giboney, J. S. (2017). Examining the learning effects of live streaming video game instruction over Twitch. Computers in Human Behavior, 77, 95-109. Available at: https://doi.org/10.1016/j.chb.2017.08.029.

Peterka-Benton, D., \& Benton, B. (2019). Globalizing online learning: Exploring culture, corporate social responsibility, and domestic violence in an international classroom. E-Learning and Digital Media, 16(4), 267-283. Available at: https://doi.org/10.1177/2042753019835890.

Rai, D., \& Khanal, Y. K. (2017). Emotional Intelligence and emotional maturity and their relationship with academic achievement of college students in Sikkim. International Journal of Education and Psychological Research, 6(2), 1-5.

Ramos-Morcillo, A. J., Leal-Costa, C., Moral-García, J. E., \& Ruzafa-Martínez, M. (2020). Experiences of nursing students during the abrupt change from face-to-face to e-learning education during the first month of confinement due to COVID-19 in Spain. International Journal of Environmental Research and Public Health, 17(15), 5519. Available at: https://doi.org/10.3390/ijerph 17155519.

Rapanta, C., Botturi, L., Goodyear, P., Guàrdia, L., \& Koole, M. (2020). Online university teaching during and after the Covid-19 crisis: Refocusing teacher presence and learning activity. Postdigital Science and Education, 2(3), 923-945. Available at: https://doi.org/10.1007/s42438-020-00155-y.

Riyahi, M., \& Sohrabi, M. K. (2020). Providing effective recommendations in discussion groups using a new hybrid recommender system based on implicit ratings and semantic similarity. Electronic Commerce Research and Applications, 40, 100938. Available at: https://doi.org/10.1016/j.elerap.2020.100938.

Sharma, S. K., Palvia, S. C. J., \& Kumar, K. (2017). Changing the landscape of higher education: From standardized learning to customized learning. Journal of Information Technology Case and Application Research, 19(2), 75-80. Available at: https://doi.org/10.1080/15228053.2017.1345214.

Shu, H., \& Gu, X. (2018). Determining the differences between online and face-to-face student-group interactions in a blended learning course. The Internet and Higher Education, 39, 13-21. Available at: https://doi.org/10.1016/j.iheduc.2018.05.003.

Siqin, T., \& Chu, S. K. W. (2019). How students take collective responsibility for productive collaboration: An empirical examination of online discourse. Interactive Learning Environments, 1-14. Available at: https://doi.org/10.1080/10494820.2019.1636081.

So, W. W. M., Chen, Y., \& Wan, Z. H. (2019). Multimedia e-learning and self-regulated science learning: A study of primary school learners' experiences and perceptions. Journal of Science Education and Technology, 28(5), 508-522. Available at: https://doi.org/10.1007/s 10956-019-09782-y.

Sugawara, R., Okuhara, S., \& Sato, Y. (2020). Study about the aptitude-treatment interaction between learning using the e-learning system and learning type of learner. International Journal of Information and Education Technology, 10(7), 488-493. Available at: https://doi.org/10.18178/ijiet.2020.10.7.1412.

Sulistyaningsih, D., \& Aziz, A. (2018). Development of learning design for mathematics manipulatives learning based on E-learning and character building. International Electronic Journal of Mathematics Education, 14(1), 197-205. Available at: https://doi.org/10.29333/iejme/3996.

Suryaman, M., Cahyono, Y., Muliansyah, D., Bustani, O., Suryani, P., Fahlevi, M., \& Munthe, A. P. (2020). COVID-19 pandemic and home online learning system: Does it affect the quality of pharmacy school learning? Syst. Rev. Pharm, 11(8), 524-530. Available at: Systematic Reviews in Pharmacy.

Tejedor, S., Cervi, L., Pérez-Escoda, A., \& Jumbo, F. T. (2020). Digital literacy and higher education during COVID-19 lockdown: Spain, Italy, and Ecuador. Publications, 8(4), 48. Available at: https://doi.org/10.3390/publications8040048.

Titarenko, L., \& Little, C. B. (2017). International cross-cultural online learning and teaching: Effective tools and approaches. American Journal of Distance Education, 31(2), 112-127. Available at: https://doi.org/10.1080/08923647.2017.1306767.

Tshewang, R., Chandra, V., \& Yeh, A. (2017). Students' and teachers' perceptions of classroom learning environment in Bhutanese eighthgrade mathematics classes. Learning Environments Research, 20(2), 269-288. Available at: https://doi.org/10.1007/s10984-0169225-6.

Wong, J., Baars, M., Davis, D., Van Der Zee, T., Houben, G.-J., \& Paas, F. (2019). Supporting self-regulated learning in online learning environments and MOOCs: A systematic review. International Journal of Human-Computer Interaction, 35(4-5), 356-373. Available at: https://doi.org/10.1080/10447318.2018.1543084.

Wu, X. (2018). Learner's privilege and responsibility: A critical examination of the experiences and perspectives of learners from Chinese backgrounds in the United States. Wen Ma \& Chuang Wang (Eds.), 2014 (Vol. 254 pp. 39.09). Charlotte, NC: Information Age Publishing.

Yaniawati, P., Kariadinata, R., Sari, N., Pramiarsih, E., \& Mariani, M. (2020). Integration of e-learning for mathematics on resource-based learning: Increasing mathematical creative thinking and self-confidence. International Journal of Emerging Technologies in Learning, 15(6), 60-78. Available at: https://doi.org/10.3991/ijet.v15io6.11915.

Yong, S.-T., Gates, P., \& Harrison, I. (2016). Digital native students-where is the evidence. The Online Journal of Nerw Horizons in Education, $6(1), 46-58$. 